\title{
The Use Of Automated Telephone Interfaces With Customers By Local Organizations: Best Practices And Exploratory Investigation Of Usage
}

Stephen B. Castleberry, University of Minnesota Duluth

Patricia A. Merrier, University of Minnesota Duluth

Tony Lewis, MBA Student, University of Minnesota Duluth

\begin{abstract}
Automated telephone systems (ATS) have been criticized by customers as a frustrating way to interact with an organization. This study seeks to discover ATS best practices, assess how many local organizations (as opposed to 1-800 call centers) are utilizing various ATSs, and determine which ATS best practices these local organizations are adopting. A list of 35 best practices were found. An exploratory examination of 400 organizations in a mid-sized mid-western city revealed that very few use an advanced ATS, with 51\% using a simple answering machine. The adoption of best practices by these organizations was quite varied. Managerial recommendations as well as future research suggestions are offered.
\end{abstract}

Keywords: Automated telephone, best practices, call center, customer interaction, voice mail, telephone system, answering machine, customer satisfaction

In recent years, the use of automated attendants to funnel customer service telephone calls has become commonplace. I'd rather speak to a real person, but in an effort to reduce costs and improve profits, many companies have made real people harder to find over the phone lines. At the same time, these companies tout their exceptional help desk services. They are even letting you know at the start of each call that your call may be monitored in order to improve customer service... When I am told that my call may be monitored, I say 'I hope it is,' back into the phone, even though I know no one will probably hear me... I continue to make comments into the phone while I am left on hold. (McManus 2006, p. 20)

Billie McHugh, a 47-year-old artist in Cincinnati, says any relief (from ATS) would be welcome. She says she once tried to get through to Northwest Airlines for five hours, trying several times each hour to find a person who could help her with a question about her frequent-flier points. 'I kept calling and calling, and every time you're forced to go through several prompts. Then when you think you're making headway, it says, 'Due to our call volume, please call later.' (Chao, 2006)

\section{INTRODUCTION}

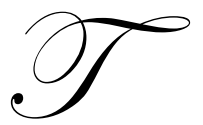

he examples just provided seem unnecessary for most people who have tried to call 1-800 call centers lately, because many have experienced similar frustrations. Research by the Harris Corporation found that only 11 percent of those surveyed were successful when using automated phone systems (ATS), and about 35 percent just press zero as soon as they are able because they don't believe the ATS is going to be able to help them (Berney 2006). As one author put it, "A Google search throws up over a 
million matches for the phrase 'call-center hell'. If you've never cursed a call center you are either: a) Job, or b) so rich you never have to call a phone company, bank, or utility yourself (Bloom 2004, p. 24).”

In fact, frustration with ATSs has caused people to search for ways to contact a live person when calling 1800 customer service centers. For example, gethuman.com lists how to maneuver call center ATSs to get to a human quickly and bypass all of the recordings ("Get A Human" 2007); the site is updated constantly by over one million consumers (Taylor 2006). Thus, although, as one consultant put it, "Customers are better informed, and have higher expectations" with regard to ATS (Cleveland 2006), the systems do not seem to be meeting customers' expectations.

It would be easy to state that since many consumers are unhappy with ATSs, organizations should replace them with live operators. But Phil Doriot (2007), a consultant with over 20 years of experience in the telecommunications industry, suggests that rather than think of callers as satisfied or dissatisfied, call centers should attempt to make improvements to their ATSs. He notes, "oversimplifying customer satisfaction [with ATS] to a black and white scenario [ keep the ATS or just drop it] increases a company's risk of making decisions that may cost them money and customers (Doriot 2007, p. 24)". His assessment seems to reflect the conclusions of many organizations today, and as a result, it does not appear that ATSs are going to go away.

So, how can a firm improve its ATS? For one thing, it can survey callers to find out what is working and what is not working. In fact, quite a number of attempts have been made to measure customer satisfaction with large 1-800 call centers (Aspect Index 2007; Stockford 2006; Noted and Noteworthy 2006: Mey 2006; Wollen 2006). The findings reveal many things that callers love and hate with regard to ATS. Later, we will highlight the major findings of these studies as we develop a list of best practices. However, it should be noted that no studies have assessed callers' satisfaction with "local" organizations (as opposed to 1-800 call centers') use of ATSs. Nor, in fact, do we know how many "local" organizations have even implemented ATSs.

Furthermore, a comprehensive listing of ATS best practices doesn't appear to exist. While a number of studies have identified a few items worth considering and many articles mention items that make people happy/angry with ATSs, no list of actual best practices has been compiled. questions:

Given the current state of knowledge about the subject, this study seeks to answer the following research

1. What are ATS best practices?

2. What percentage of local organizations and businesses are using ATSs and what are the profile differences between those who use ATSs and those who do not?

3. To what extent are best practices (identified in research question 1) being implemented by local organizations and businesses?

\section{TYPES OF AUTOMATED TELEPHONE SYSTEMS}

In surveying the literature, no clear definition of ATS could be found. In fact, a firm might automate its phone system many different ways. Some use highly sophisticated systems; others, simple automation aids. For the purposes of this study, the following conceptual definition is used: An ATS is that portion of a telephone interface between an organization and another party (e.g., customer, business) that is not a live human voice.

Since ATSs come in many varieties, the following topology was developed for use in this study:

Type 1: Simple answering machine with option only to leave a message (i.e., no option to leave a message to a specific person or department's private phone mail box). 
Type 2: Answering machine with option only to leave a message targeted to a specific phone mailbox (i.e., can only leave a message to that person or department). This ATS cannot actually transfer a caller to a phone in order to talk to a live person.

Type 3: Answering machine with option of being transferred to a specific person or phone (e.g., departments, individuals). If that person is not available to take the call, then an option might exist to leave a message for him or her.

Type 4: ATS with the characteristics of Type 3, that also includes any of a number of additional, more advanced features such as caller login, sophisticated error recovery prompts, etc.

Type 5: ATS that automatically dials from an organization to individual phone numbers. For example, a dental office that uses an ATS to call (without a human participating in the outgoing conversation) to remind patients of an upcoming appointment. Since this is an outbound system, this type of ATS is not covered in the current study.

\section{METHODOLOGY}

In order to identify best practices, an intensive search was undertaken, including examining relevant books, journal articles, popular press publications, and web sites. The goal was to be all-inclusive. If the source claimed that a particular practice was best, we assumed that assertion was correct.

A mid-sized Midwestern U.S. city was chosen as the population of interest for this study. The city has population of approximately 90,000, and the MSA has approximately 275,000 in population. In order to get a list of all possible organizations, we utilized a fully-functional version of Reference USA, a commercial database that provides lists that include every conceivable type of organization (e.g., schools, businesses, religious institutions, non-profits, service providers, government entities, etc.).

Reference USA constantly updates both the list itself and pertinent demographic information about the organizations. The city chosen has a total of 5,936 organizations listed in Reference USA. To determine the sample size needed for an accurate representation of the city's organizations, a recognized standard sample size formula for proportions was utilized (McDaniel and Gates 2007). Desiring 95 percent confidence, with plus or minus 5 percent accuracy, and using a p of .5 (since we don't know the actual population proportion for our survey questions) the formula suggested a sample size of 400 . We used a systematic sample, with a skip pattern of choosing every $15^{\text {th }}$ organization listed on Reference USA, resulting in the desired sample size of 400.

The procedure outlined by Neuendort (2002) for conducting content analyses was followed. A codebook (check off sheet) and procedures were developed and revised after pretests were conducted. Three MBA students were trained as judges; one student was designated as the primary judge, one was designated as a secondary judge, and the third was used to resolve evaluation discrepancies. All judges gathered information independent of each other.

To determine what type of ATS an organization had, as well as to determine whether it was using best practices, the primary judge dialed the phone number listed on Reference USA for that organization and audiorecorded the call. This judge was instructed to let the phone ring a maximum of ten times. If the phone was not answered by a person or an ATS, the judge hung up and proceeded to the next name. If a person answered, the judge briefly explained the purpose of the study and then ended the conversation. All calls were made between 10 AM and 4 PM, Monday through Friday - times when callers might reasonably expect to speak directly with a person in an organization or business. All data was collected from March-May of 2007.

The primary judge used a structured survey form, which included a listing of best practices (e.g., number of options at each level, how soon they were given the option of connecting to a live person, what happened if the judge didn't push any numbers, was the system voice activated or must the caller push numbers, etc.). In addition, following recommendations of Kassarjian (1977), a second evaluator (secondary judge) reviewed 10 percent of the 
calls to insure reliability of the results. The coefficient of reliability between the two judges was 89.8 percent, exceeding Kassarjian's suggested minimum of 85 percent agreement. The few differences that were observed between the primary and secondary judges were resolved by the third judge.

Table 1

Best Practices for Automated Telephone Systems

\section{Have an effective greeting and beginning to the interaction}

1. Offer a welcoming greeting

2. Provide language options (e.g. Spanish, English)

3. Inform caller that they are working with an automated system

4. Inform caller how to reach a human operator

5. Way to reach operator should be standard: either press " 0 " or say "operator"

6. Inform caller of error recovery method

7. Use personalization through caller ID or by having the caller log in

8. Inform caller of system limitations

9. If requested by the caller, route to a live operator, rather than voice mailbox

\section{Have effective and efficient call processing}

1. Include speech recognition

2. Touchtone keypad entry possible

3. Short wait time after caller's response before the system replies

4. Allow adequate time for a requested action from the caller

5. Wait time filler is relevant information (not recorded music or a radio station)

6. Small number of menu options presented in a single prompt

7. Choices that are arranged logically

8. Give constructive feedback when the customer is on the right track

9. $\quad$ Voice interface that is natural

10. Highly professional persona, rather than an animated persona (an animated persona can often be seen as annoying)

11. Error recovery prompts using successive levels of error handling (instead of repeating the same instructions over and over again)

12. Caller progress that is not interrupted by marketing offers (either internal or external to the organization) since this always lowers customer satisfaction regardless of how politely it is done

13. ATS that is courteous, not castigating the user for incorrect or slow responses

14. ATS that is relationship oriented, rather than simply highly-task oriented

15. Summary instructions or a closing statement are provided

\section{With regard to the human operator interface:}

1. Give an estimate of the time to connect to a human operator

2. Operator should be courteous

\section{Additional best practices that could not be assessed in this study}

1. Use latest available software (e.g., sound-filtering voice recognition software)

2. Personalized; linked to prior transactions (personalization and profiling)

3. Emotion detection technology employed to see if the caller is agitated or angry

4. Voice interface that is an appropriate persona (female, male, androgynous)

5. Appropriate testing of the ATS (look for choke points - points where it is difficult for the caller to go from one point to another; look for points where many callers are balking, have older callers test the system rather than young callers)

6. Operators who are knowledgeable about the ATS and can give instructions on how to use it

7. Operator has information about the customer and what information the customer has already input into the call to reduce redundant information gathering

8. Do not try to do too much with the ATS (automate the top three or four interactions and direct the minority to a human operator; concentrate on tasks that the user would prefer to complete without talking to a human)

9. Use an appropriate vocabulary for the audience (not complex terminology or jargon) 


\section{FINDINGS}

\section{Best Practices}

Table 1 provides a listing of best practices suggested by the literature described earlier. While much of these best practices seem to be based on anecdotal wisdom, some are based on published empirical studies. As an example of an empirical study, 65 percent of respondents in one study said they preferred speech recognition to touch-tone entries, and 85 percent said they find current speech recognition systems to be satisfactory or better (Zager, 2005).

\section{Profiles Of Organizations That Utilize Various ATS Types}

The second research question was what percentage of local organizations and businesses are using ATSs and what are the differences in terms of profiles between those that use ATSs and those that do not? Table 2 summarizes the findings.

Table 2

Characteristics of Organizations With Various ATS Types

\begin{tabular}{|c|c|c|c|c|c|}
\hline & $\begin{array}{c}\text { Type } 1 \\
\text { Simple } \\
\text { answering } \\
\text { machine } \\
\end{array}$ & $\begin{array}{c}\text { Type } 2 \\
\text { Answering machine } \\
\text { with voice mail to } \\
\text { specific persons } \\
\end{array}$ & $\begin{array}{c}\text { Type } 3 \\
\text { Answering machine; } \\
\text { can be transferred to } \\
\text { a live person }\end{array}$ & $\begin{array}{c}\text { Type } 4 \\
\text { Advanced } \\
\text { ATS }\end{array}$ & $\begin{array}{c}\text { No ATS } \\
\text { (only a live } \\
\text { person) }\end{array}$ \\
\hline $\begin{array}{l}\text { Percentage of Organizations } \\
\text { With Each Type of ATS }\end{array}$ & $51 \%$ & $4 \%$ & $13 \%$ & $.5 \%$ & $33 \%$ \\
\hline Average Number of employees ${ }^{1}$ & 9 & 39 & 19 & 20 & 23 \\
\hline \multicolumn{6}{|l|}{ Sales Volume $^{2}$} \\
\hline Less than $\$ 500 \mathrm{~K}$ & $56 \%$ & $62 \%$ & $30 \%$ & & $31 \%$ \\
\hline$\$ 500 \mathrm{~K}-1 \mathrm{M}$ & $24 \%$ & $8 \%$ & $13 \%$ & $100 \%$ & $32 \%$ \\
\hline$\$ 1-5 \mathrm{M}$ & 15 & $15 \%$ & $40 \%$ & & $31 \%$ \\
\hline$\$ 5 \mathrm{M}+$ & $6 \%$ & $15 \%$ & $18 \%$ & & $7 \%$ \\
\hline \multicolumn{6}{|l|}{ Location $^{3}$} \\
\hline Single location & $95 \%$ & $94 \%$ & $86 \%$ & $50 \%$ & $79 \%$ \\
\hline Branch or subsidiary & $5 \%$ & $6 \%$ & $14 \%$ & $50 \%$ & $21 \%$ \\
\hline
\end{tabular}

2 Chi Square $=24.04, \mathrm{df}=6, \mathrm{p}=.001$ (excluding Complex ATS)

3 Chi Square $=4.47, \mathrm{df}=2, \mathrm{p}=.107$ (excluding Complex ATS)

Most "local businesses" have a simple answering machine, although about a third have no type of ATS at all, not even an answering machine. Organizations that had a simple answering machine tend to have relatively few employees (average of 9 employees), while those organizations with answering machines/with voice mail to specific persons had the largest number (average of 39 employees). However, as Table 2 indicates, there is not a linear relationship between the number of employees and the complexity of the ATS. For example, those with only a live operator had on average 23 employees.

In terms of sales volume, there is a significant relationship with ATS type, although the exact nature of this relationship is difficult to ascertain (see Table 2). It appears that those with a simple answering machine or the ability to leave a message with a specific person tend to have smaller sales volumes, while those with answering 
machines that can be transferred to a live person have higher sales volumes. However, organizations with no ATS have a wide variance in terms of sales volumes. There is no significant relationship between ATS type and whether the local business is a single location or a branch/subsidiary of a larger organization (see Table 2).

What impact does the activity of the organization have upon the ATS type? To explore that question, cross-tabulations of ATS type with NAICS descriptions were conducted, with the results displayed in Table 3. NAICS is the United States' North American Industry Classification System, which replaced the well-known SIC system. Table 3 lists the NAICS descriptions only for those types of organizations that rely exclusively on a single type of ATS. In other words, every sports and recreation instruction organization in our study had a simple answering machine only, and all motor vehicle dealers had no ATS (only a live operator).

Table 3

NAICS Descriptions by ATS: All organizations of that type have only one type of ATS

\begin{tabular}{|c|c|c|c|}
\hline $\begin{array}{c}\text { Simple answering machine } \\
\text { only (Type 1) }\end{array}$ & $\begin{array}{c}\text { Answering machine with } \\
\text { voice mail to specific } \\
\text { persons (Type 2) }\end{array}$ & $\begin{array}{l}\text { Answering machine that } \\
\text { can transfer to a live } \\
\text { person (Type 3) }\end{array}$ & $\begin{array}{c}\text { No ATS (only a live } \\
\text { person) }\end{array}$ \\
\hline $\begin{array}{l}\text { *Administration of general } \\
\text { economic programs } \\
* \text { Durable goods wholesalers } \\
* \text { Health stores } \\
* \text { Personal services } \\
* \text { Amusement arcades } \\
* \text { Architectural services } \\
\text { * Automotive parts } \\
\text { * Bed \& breakfast } \\
\text { * Boat dealers } \\
\text { * Convention and visitors } \\
\text { bureaus } \\
* \text { Civic and social } \\
\text { organizations } \\
* \text { Electrical contractors } \\
\text { * Drywall and insulation } \\
\text { contractors } \\
* \text { Elementary and secondary } \\
\text { schools } \\
* \text { Janitorial services } \\
\text { * Landscaping services } \\
* \text { Lessors of residential } \\
\text { buildings } \\
* \text { Photographic studios, } \\
\text { portrait } \\
* \text { Process and logistics } \\
\text { consulting services } \\
* \text { Sports and recreation } \\
\text { instruction }\end{array}$ & $\begin{array}{l}\text { * Bowling centers } \\
* \text { Business associations } \\
* \text { Nursing care facility }\end{array}$ & $\begin{array}{l}\text { *Non depository credit } \\
\text { intermediation } \\
* \text { Credit unions } \\
* \text { Dairy products wholesaler } \\
\text { * Investment advice } \\
\text { * Kidney dialysis center } \\
\text { * Human resource program } \\
\text { administration } \\
\text { * Support activities for } \\
\text { forestry } \\
* \text { Television broadcasting } \\
* \text { Title abstract and } \\
\text { settlement offices }\end{array}$ & $\begin{array}{l}\text { * Motor vehicle dealers } \\
* \text { Auto transmission repair } \\
* \text { Barber shops } \\
\text { * Beer, wine, and liquor } \\
\text { stores } \\
\text { * Camera supplies stores } \\
\text { * Charter bus industry } \\
\text { * Convenience stores } \\
\text { * Drinking places, alcoholic } \\
\text { beverages } \\
\text { * Florists } \\
\text { * Full-service restaurants } \\
\text { * Legal counsel and } \\
\text { prosecution } \\
* \text { Men's clothing stores } \\
\text { * Misc. Schools and } \\
\text { instruction } \\
* \text { Museums } \\
\text { * Offices of specialty } \\
\text { therapists } \\
* \text { Mechanical and Electrical } \\
\text { Repair }\end{array}$ \\
\hline
\end{tabular}

Upon examining Table 3 carefully, it is difficult to see any patterns that emerge. In fact, it would appear that organizations of all types are represented in each column. For example, service organizations as well as providers of products are listed in all columns. In addition, both for-profit and not-for-profit organizations are represented in each column.

This finding is further revealed when one examines those types of organizations (by NAICS description) which do not all have just one type of ATS. For example, the following NAICS organizations had firms with at 
least three different types of ATS: engineering services, insurance agencies and brokerages, offices of certified public accountants, offices of lawyers, offices of physicians (except mental health), and religious organizations.

\section{Extent To Which Best Practices Are Being Implemented}

Table 4 summarizes the use of best practices by ATS type. Surprisingly, many of the rather simple best practices are not being adopted by a majority of local organizations (e.g., informing caller of recovery method, informing caller of system limitations, giving constructive feedback when the customer is on the right track, providing relevant wait filler information). The lack of bilingual instructions (e.g., English/Spanish) perhaps simply reflects the demographics of the area: only about one percent are Hispanic or Latino.

Table 4

Utilization of Best Practices by ATS Type

\begin{tabular}{|c|c|c|c|c|}
\hline & $\begin{array}{c}\text { Type 1 } \\
\text { Simple } \\
\text { Answering } \\
\text { Machine }\end{array}$ & $\begin{array}{c}\text { Type 2 } \\
\text { Answering } \\
\text { machine with } \\
\text { voice mail to a } \\
\text { specific person } \\
\end{array}$ & $\begin{array}{c}\text { Type } 3 \\
\text { Answering } \\
\text { machine; can be } \\
\text { transferred to a } \\
\text { live person } \\
\end{array}$ & $\begin{array}{c}\text { Type } 4 \\
\text { Advanced ATS }\end{array}$ \\
\hline \multicolumn{5}{|l|}{$\begin{array}{l}\text { Have an effective greeting and beginning to the } \\
\text { interaction }\end{array}$} \\
\hline Offer a welcoming greeting & $86 \%$ & $100 \%$ & $83 \%$ & $100 \%$ \\
\hline Provide language options (e.g. Spanish, English) & $1 \%$ & $0 \%$ & $0 \%$ & $0 \%$ \\
\hline $\begin{array}{l}\text { Inform caller that they are working with an } \\
\text { automated system }\end{array}$ & $22 \%$ & $100 \%$ & $100 \%$ & $100 \%$ \\
\hline Inform caller how to reach a human operator & $22 \%$ & $100 \%$ & $100 \%$ & $100 \%$ \\
\hline $\begin{array}{l}\text { Way to reach operator should be standard: either } \\
\text { press " } 0 \text { " or say "operator }\end{array}$ & $0 \%$ & $0 \%$ & $4 \%$ & $0 \%$ \\
\hline Inform caller of error recovery method & $1 \%$ & $0 \%$ & $26 \%$ & $0 \%$ \\
\hline $\begin{array}{l}\text { Use personalization through caller ID or by } \\
\text { having the caller log in }\end{array}$ & $0 \%$ & $0 \%$ & $0 \%$ & $0 \%$ \\
\hline Inform caller of system limitations & $0 \%$ & $0 \%$ & $4 \%$ & $0 \%$ \\
\hline \multicolumn{5}{|l|}{ Have effective and efficient call processing } \\
\hline Include speech recognition & $0 \%$ & $0 \%$ & $0 \%$ & $50 \%$ \\
\hline Touchtone keypad entry possible & $20 \%$ & $100 \%$ & $100 \%$ & $100 \%$ \\
\hline $\begin{array}{l}\text { Short wait time after caller's response before the } \\
\text { system replies }\end{array}$ & $\begin{array}{c}\text { less than } 1 \\
\text { second }=100 \%\end{array}$ & $\begin{array}{c}\text { less than } 1 \\
\text { second }=100 \%\end{array}$ & $\begin{array}{c}\text { less than } 1 \\
\text { second }=100 \%\end{array}$ & $\begin{array}{c}\text { less than } 1 \\
\text { second }=100 \%\end{array}$ \\
\hline $\begin{array}{l}\text { Wait time filler is relevant information (not } \\
\text { recorded music or a radio station) }\end{array}$ & $\begin{array}{c}1 \%=\text { music } \\
99 \%=\text { no wait }\end{array}$ & $\begin{array}{l}6 \%=\text { dead air } \\
94 \%=\text { no wait }\end{array}$ & $\begin{array}{c}50 \%=\text { busy } \\
\text { signal of dial } \\
\text { tone } \\
19 \%=\text { music } \\
\text { only } \\
6 \%=\text { music and } \\
\text { pertinent info } \\
6 \%=\text { music/info/ } \\
\text { ads } \\
19 \%=\text { no wait }\end{array}$ & $100 \%=$ no wait \\
\hline $\begin{array}{l}\text { Small number of menu options presented in a } \\
\text { single prompt }\end{array}$ & NA & $\begin{array}{c}0=2.75 \\
\text { Range } 2-4\end{array}$ & $\begin{array}{c}0=5.13 \\
\text { Range 2-20 }\end{array}$ & $\begin{array}{c}0=4 \\
\text { Range 3-5 }\end{array}$ \\
\hline Choices that are arranged logically & NA & $100 \%$ & $83 \%$ & $50 \%$ \\
\hline $\begin{array}{l}\text { Give constructive feedback when the customer is } \\
\text { on the right track }\end{array}$ & $25 \%$ & $0 \%$ & $30 \%$ & $50 \%$ \\
\hline Voice interface that is natural ${ }^{1}$ & $\begin{array}{c}0=5.76 \\
\text { Range }=1-6\end{array}$ & $\begin{array}{c}0=6.00 \\
\text { Range }=6-6\end{array}$ & $\begin{array}{c}0=5.78 \\
\text { Range }=3-6\end{array}$ & $\begin{array}{c}0=5.00 \\
\text { Range }=4-6\end{array}$ \\
\hline
\end{tabular}




\begin{tabular}{|c|c|c|c|c|}
\hline \multicolumn{5}{|c|}{ Table 4 continued } \\
\hline $\begin{array}{l}\text { Highly professional persona, rather than an } \\
\text { animated persona (an animated persona can often } \\
\text { be seen as annoying) }\end{array}$ & $\begin{array}{c}0=1.13 \\
\text { Range }=1-4\end{array}$ & $\begin{array}{c}0=1.25 \\
\text { Range }=1-2\end{array}$ & $\begin{array}{c}0=1.04 \\
\text { Range }=1-2\end{array}$ & $\begin{array}{c}0=1.00 \\
\text { Range }=1-1\end{array}$ \\
\hline $\begin{array}{l}\text { Error recovery prompts using successive levels of } \\
\text { error handling (instead of repeating the same } \\
\text { instructions over and over again) }\end{array}$ & $0 \%$ & $0 \%$ & $9 \%$ & $50 \%$ \\
\hline $\begin{array}{l}\text { Caller progress that is not interrupted by } \\
\text { marketing offers (either internal or external to the } \\
\text { organization) }\end{array}$ & $100 \%$ & $100 \%$ & $100 \%$ & $100 \%$ \\
\hline $\begin{array}{l}\text { ATS that is courteous, not castigating the user for } \\
\text { incorrect or slow responses } 3\end{array}$ & $\begin{array}{c}0=1.00 \\
\text { Range }=1-1\end{array}$ & $\begin{array}{c}0=1.00 \\
\text { Range }=1-1\end{array}$ & $\begin{array}{c}0=1.00 \\
\text { Range }=1-1\end{array}$ & $\begin{array}{c}0=1.00 \\
\text { Range }=1-1\end{array}$ \\
\hline $\begin{array}{l}\text { ATS that is relationship oriented, rather than } \\
\text { simply highly-task oriented }{ }^{4}\end{array}$ & $\begin{array}{c}0=1.5 \\
\text { Range }=1-3\end{array}$ & $\begin{array}{c}0=1.00 \\
\text { Range }=1-1\end{array}$ & $\begin{array}{c}0=1.09 \\
\text { Range }=1-3\end{array}$ & $\begin{array}{c}0=1.00 \\
\text { Range }=1-1\end{array}$ \\
\hline $\begin{array}{l}\text { Summary instructions or a closing statement are } \\
\text { provided }\end{array}$ & $70 \%$ & $100 \%$ & $52 \%$ & $50 \%$ \\
\hline \multicolumn{5}{|l|}{ With regard to the human operator interface: } \\
\hline $\begin{array}{l}\text { Give an estimate of the time to connect to a } \\
\text { human operator }\end{array}$ & N/A & $0 \%$ & $0 \%$ & $0 \%$ \\
\hline Operator should be courteous ${ }^{5}$ & N/A & $\begin{array}{c}0=2.33 \\
\text { Range }=1-3\end{array}$ & $\begin{array}{c}0=1.87 \\
\text { Range }=1-3\end{array}$ & $\begin{array}{c}0=1.00 \\
\text { Range }=1-1\end{array}$ \\
\hline
\end{tabular}

\section{Limitations}

It is possible that some organizations might have a different phone number, not readily available to the public, which they offer their customers. If so, this different phone number might incorporate more sophisticated ATS features. For example, a bank may have a "normal" phone number for callers (that is listed in the phone book and that would also be provided to Reference USA), but have a different number that customers can call to check their account balance, transfer funds, etc. There was no way to assess such a phone number in the current study given our methodology and the fact that the judge wouldn't be a current customer of all organizations listed.

While the inter-rater reliability in this study was adequate, a higher level could be preferred. Although all judges were MBA students, differences certainly exist among them in terms of their perceptions of various items. Every effort was made to reduce such differences by clearly delineating the items being checked. However, a few items on the survey did require a more subjective assessment. It was usually these items that resulted in different ratings between the primary judge and the first secondary judge. However, when the third judge resolved such disputes, it was found that the differences were usually very minor. For example, for one item, Judge 1 gave a rating of 5 (out of a possible 6), while Judge 2 gave a rating of 4 .

\section{CONCLUSIONS AND MANAGERIAL IMPLICATIONS}

The results of this study suggest that local organizations are slow to adopt ATS technology. Approximately one-third (33 percent) of the population surveyed in this study did not use an ATS. Among those that did, over half (51 percent) used a basic answering machine, and only 0.5 percent used an advanced ATS. This may reflect local organizations' desire to avoid the pitfalls and customer dissatisfaction with complex ATSs that were mentioned at the first of this article. On the other hand, it may also reflect a lack of awareness of ATS advantages and capabilities. In that regard, some local organizations may represent an untapped market for ATS providers.

Although many of the best practices assessed in this study do not apply to basic answering machines, many that do apply are not being implemented at the local organization level. Practices as basic as offer a welcoming greeting, inform caller that he/she has reached an automated system, and inform caller of system limitations failed 
to yield 100 percent usage across all ATS types. Thanking callers for phoning is courteous and parallels the greeting a person might use if he/she were answering the phone (Thank you for calling ABC Company; how may I help you?) and can temper the frustration a caller might feel if he/she expected a human to answer. Stating that the caller has reached an ATS is also courteous. High-quality recordings sound so natural that an announcement is necessary to notify the caller that he/she is not speaking to a live person. Alerting callers to recording time maximums or other system limitations that may affect their interaction with the ATS will enhance the overall communication experience.

Other suggestions for practitioners are also afforded by the findings. Nineteen percent of those with a Type 3 ATS have only music playing during the wait time. Once again, best practices (see Table 1) suggest that such music should be replaced with pertinent information.

In summary, managers should look at the list of best practices (Table 1) and consider implementing them, regardless of the type of ATS deployed. Best practices are linked to customer satisfaction, a goal of all organizations.

\section{FUTURE RESEARCH}

The list of best practices used in this study was compiled from a variety of sources. Best practices should be verified through empirical studies, not merely anecdotal evidence. Such research should consider whether demographic variables such as age and experience with technology influence user satisfaction.

Future research about ATSs needs to focus on a larger sample than was used in this study. Similarly, the demographic characteristics of the sample need to be expanded. For example, respondents should be drawn from cities/towns of various sizes and geographic regions to get a better sense of the types of ATSs that are being used.

Finally, research should be conducted to determine whether e-mail and the growing use of web sites has influenced local organizations' use of ATS.

\section{ACKNOWLEDGEMENTS} this project.

Special thanks to Connie O'Brien and Nancy Nilsen, who aided in data collection, coding, and analysis for

\section{REFERENCES}

1. Aspect Index (2007), The 2007 Aspect Contact Center Satisfaction Index - North America. As viewed on June 23, 2006 at http://www.aspectindex.com/index_na/

2. Bailor, Coreen (2005), Avoiding the Speech Rec., Customer Relationship Management, (November), 3942.

3. Berney, Louis (2006), Aetna Customers Talk Back, Insurance Networking News: Executive Strategies for Technology Management, 9 (7), (February), 8.

4. Biermann, Alan W.; R. B. Inouye, and Ashley McKenzie (2005), Methodologies for Automated Telephone Answering, Foundations of Intelligent Systems: 15th International Symposium; Lecture Notes in Artificial Intelligence, v3488 (May 25-28 2005), 1-13.

5. Bloom, Jonah (2004), A Calm, Cool Emily Could be Answer to Dante's Call Centers, Advertising Age, 75 (37), (September 13), 24.

6. Chao, Loretta (2006, August 8), Stuck in a Phone Tree: Some Companies Try to Make Escape Easier, The Wall Street Journal (Eastern edition), D1.

7. Cleveland, Brad (2006), Preparing Your Call Center for Tomorrow's Environment: Six Key Trends to Consider, Call Center, 19 (9), September 1, p. 32. 
8. Doriot, Phil (2007), Five Myths About Customer Satisfaction - What You Don’t Know About Measuring Customer Happiness CAN Hurt Your Bottom Line, According to One Expert, Call Center, 20 (1), January 1, p. 24.

9. Froehle, Craig M. (2006), Service Personnel, Technology, and Their Interaction in Influencing Customer Satisfaction, Decision Sciences, 37 (1), 5-38.

10. Get a Human (2007), in Your Money section, AARP Bulletin, January, 28.

11. Hoslinger, Dave (2005), Optimizing the Inbound Phone channel to Better Reach Your Customers, Customer Interaction Solutions, 24 (3), (September), 48.

12. Kaiser, Lizanne (2004), The Balancing Act: Using Touch-Tone and Speech, Business Communications Review, 34 (11), (November) 58.

13. Kassarjian, H.H.(1977), Content Analysis in Consumer Research, Journal of Consumer Research 4 (June), $8-18$.

14. Kolberg, Mario and Evan H. Magill (2006), Managing Feature Interactions Between Distributed SIP Call Control Services, Computer Networks, 51 (2007), 536-557.

15. Kwan, Min Lee and Jennifer Lai (2005), Speech Versus Touch: A Comparative Study of the Use of Speech and DTMF Keypad for Navigation, International Journal of Human-Computer Interaction, 19 (3), 343360 .

16. Lieber, Ron (2002, July 30), Operator, I Demand an Automated Menu - More Companies Train Staff to Aggressively Pitch Callers Seeking Customer Service, The Wall Street Journal (Eastern edition), D1.

17. McManus, Kevin (2006), Your Call May Be Monitored, Industrial Engineer, 38 (9) September, p. 20.

18. Mey, Kurt (2006), North American Contact Centers: Why Are We Falling Behind? Customer Interaction Solutions, 24 (9) March, p. 56.

19. $\quad$ Noted and Noteworthy (2006), US Banker, 116 (8), August, p. 16.

20. Pulfer, Rachel (2006), The Phone-Service Test, Canadian Business, 79 (20), (October 9), 137-139

21. Rayport, Jeffrey F.; Bernard J. Jaworski and Ellie J. Kyung (2005), Best Face Forward: Improving Companies' Service Interfaces With Customers, Journal of Interactive Marketing, 19 (Autumn), 67-80.

22. Rolandi, Walter (2007), Decrease IVR Hang-Ups, Customer Relationship Management, (February), 12.

23. Rosales, Mauricion (2006), Business Class SLAs for VOIP Services Business Communications Review (July), 36-39.

24. Sharit, Joseph; Sar J. Czaja, Sankaran Nair and Chin Chin Lee (2003), Effects of Age, Speech Rate, and Environmental Support in Using Telephone Vice Menu Systems, Human Factors 45 (2), (Summer), 234251.

25. Suhm, Bernhard and Pat Peterson (2001), A Data-Driven Methodology for Evaluating and Optimizing Call Center IVRs, International Journal of Speech Technology, 5 (2002), 23-37.

26. Stockford, Paul, Customer Care Perception vs. Reality - The Aspect Index Reveals a Grand Canyon-sized Chasm Between Centers and Their Customers When It Comes to Satisfaction, Call Center, 22 (May 1), as viewed in the RDS Suite: Business \& Management Practices.

27. Taylor, William C., (2006, February 26), Your Call Should be Important to Us, but It's Not, The New York Times (Late Edition) (East Coast), 3.

28. Turner, Kenneth J. (2004), Analyzing Interactive Voice Services, Computer Networks, 45 (2004), $665-685$.

29. ---- and Lynne Blair (2007), Policies and Conflicts in Call Control, Computer Networks, 51 (2007), 496514.

30. van Birgelen, Marcel; Ad de Jong, and Ko de Ruyter (2006), Multi-Channel Service Retailing: The Effects of Channel Performance Satisfaction on Behavioral Intentions, Journal of Retailing, 82 (4, 2006), 367-377.

31. Urbina, Ian (2004), Your Train Will Be Late, She Says Cheerily, New York Times, Vol 154, Issue 53054, November 24, p. B1-B2.

32. Wilkie, J.; M. A. Jack, and P. J. Littlewood (2005), System-Initiated Digressive Proposals in Automated Human-Computer Telephone Dialogues: The Use of Contrasting Politeness Strategies, International Journal of Human-Computer Studies, 62 (2005), 41-71.

33. Wollen, Robert (2006), CIO's and the Battle for Consumers: To Win Over Customers, Banks Must Understand the Kind of Service Customers Demand, Bank Systems \& Technology, 43 (2), February, p. 41.

34. Zager, Masha (2005), Speech Recognition Goes Mainstream- Why Speech Recognition is Emerging as an Essential Component of Customer Service, Call Center, 20 (October 1). 
35. Zajicek, Mary; Richard Wales, and Andrew Lee (2004), Speech Interaction for Older Adults, Univ Access Inf Soc 3 (2004), 122-130.

1. 6-point scale with endpoints of $1=$ very synthesized voice, $6=$ very natural voice

2. 5-point scale with endpoints of $1=$ Highly professional voice, $5=$ Unprofessional , highly animated voice

3. 5-point scale with endpoints of $1=$ highly courteous, $5=$ very rude

4. 5-point scale with endpoints of $1=$ task oriented, $5=$ relationship oriented

5. 5-point scale with endpoints of $1=$ very courteous, $5=$ very rude

\section{NOTES}




\section{NOTES}

